\title{
Conservation biogeography in the Mexican Mountain Component: bridging conservation and patterns of endemism
}

\author{
Ricardo Morales ${ }^{1}$, Tania Escalante ${ }^{1 *}$, Elkin A. Noguera-Urbano ${ }^{1}$, Niza Gámez ${ }^{1}$ and Gerardo Rodríguez-Tapia² \\ 1) Grupo de Biogeografía de la Conservación, Departamento de Biología Evolutiva, Facultad de Ciencias, Universidad Nacional \\ Autónoma de México. Circuito Exterior s/n, Ciudad Universitaria, Coyoacán, 04510. Ciudad de México, México. E-mail: truchatu@ \\ gmail.com (RM), tee@st.ib.unam.mx (TE), elkalexno@gmail.com (EANU), nizagt@gmail.com (NG). \\ 2) Unidad de Geomática, Instituto de Ecología, Universidad Nacional Autónoma de México. Apartado Postal 70-275, Coyoacán, \\ 04510, Ciudad de México, México. E-mail: gerardo@ecologia.unam.mx (GRT). \\ ${ }^{*}$ Corresponding author
}

The Mexican Mountain Component (MMC) includes six biogeographical provinces. In this manuscript, we propose to use endemic taxa as surrogates to prioritize for conservation areas of the MMC. We use the distribution of 24 endemic mammals to prioritize conservation sites in the $M M C$ and to evaluate the current Mexican system of protected natural areas (PNA). We used species distribution models and the software ConsNet 2.0 to prioritize areas for conservation, evaluating two algorithms (the representation maximization problem, and the area minimization problem) and two different representation targets (10\% and $25 \%$ ) of the distributional area of endemic taxa. In addition, we considered the effects of including existing PNA and/or excluding areas with altered vegetation. The representation maximization problem including current PNA was ineffective for reaching conservation targets. Meanwhile, all area minimization problems allowed us to prioritize areas reaching the targets of surrogates. In particular, a strategy that considers area minimization problem using a target of $10 \%$ of the distribution of surrogates, including PNA and excluding the altered vegetation, was the most favorable for maintaining the distributional patterns of the endemic mammals. This solution proposes the protection of a total of $37,460 \mathrm{~km}^{2}$, covering areas with altitude above $2,400 \mathrm{~m}$ located mainly in the Sierra Madre Occidental, the Transmexican Volcanic Belt, and provinces of the Sierra Madre del Sur. A prioritization strategy based on the distribution of endemic mammals as surrogates can help to maintain the distributional patterns of endemism of the Mexican biota.

El Componente Mexicano de Montaña (CMM) ocupa los principales sistemas montañosos de México, incluyendo seis provincias biogeográficas. En este manuscrito, proponemos que los taxones endémicos pueden ser utilizados para priorizar áreas de conservación en el CMM. Se priorizaron sitios de conservación con base en la distribución de 24 mamíferos endémicos; seguidamente se evaluó el sistema de áreas naturales protegidas (ANP) de México, a través de la representación de los mamíferos endémicos. Se utilizaron modelos de distribución de especies y el software ConsNet 2.0 para priorizar áreas de conservación, empleando dos algoritmos: el problema de máxima representación y el problema de área mínima. Además, se utilizaron dos metas de representación: 10 \% y $25 \%$ del área de distribución de las especies endémicos. Además, se consideraron las ANP existentes y se excluyeron áreas de vegetación alterada para algunos ejercicios. El problema de representación máxima, incluyendo las ANP actuales, fue ineficaz para alcanzar las metas de conservación. Mientras, todos los problemas de área mínima permitieron priorizar áreas que alcanzan las metas de los subrogados. En particular, la estrategia que considera el problema de área mínima con un objetivo del $10 \%$ de la distribución de los subrogados (incluidas las ANP y excluyendo la vegetación alterada) puede ayudar a mantener los patrones de distribución de endemismo en la biota mexicana. Esta estrategia incluye $37,460 \mathrm{~km}^{2}$, cubriendo áreas por encima de los 2,400 metros y que se encuentran principalmente en la Sierra Madre Occidental, la Faja Volcánica Transmexicana, y las provincias de la Sierra Madre del Sur. Una estrategia basada en áreas priorizadas en función de los mamíferos endémicos como subrogados puede ayudar a mantener los patrones de distribución de endemismo de la biota mexicana.

Key words: conservation biogeography; endemicity; mammals; Mexico; surrogates; sympatry.

๑) 2016 Asociación Mexicana de Mastozoología, www.mastozoologiamexicana.org 


\section{Introduction}

Whittaker et al. (2005, p. 4) defined conservation biogeography as "the application of biogeographical principles, theories, and analyses, being those concerned with the distributional dynamics of taxa individually and collectively, to problems concerning the conservation of biodiversity". Although biogeographic patterns have been used as criteria for area prioritization, many of them are limited to current patterns (such as species richness), but evolutionary patterns are, in general, missing (Luna-Vega et al. 2010).

Two main criteria are used to incorporate evolutionary approaches: 1) taxonomic distinctness or phylogenetic diversity, and 2) geographic distributional patterns (Vane-Wright et al. 1991; Posadas et al. 2001; Faith et al. 2004). On one hand, phylogenetic diversity is a measure of the "uniqueness" of taxa, which allows ranking areas for conservation on the basis of information encoded in phylogenies (Posadas et al. 2001). On the other hand, endemic taxa (as traditionally defined, those confined to political divisions or micro-areal) have been included as surrogates in Systematic Conservation Planning (SCP; Margules and Sarkar 2007) considering that their persistence requires immediate conservation actions. However, inclusion of endemic taxa does not guarantee the representation of overall species diversity (Bonn et al. 2002). Other approaches, such as phylogenetic endemism, have been used more recently (Rosauer and Jetz 2014).

An alternative view considering endemism as a pattern of geographical distribution, rather than restricted to political entities may also be used as a surrogate in SCP. In this concept, taxa restricted to natural units are recognized as endemic, and areas of endemism are diagnosed by shared distributional boundaries of two or more endemic species (Morrone 1994, Morrone and Escalante 2009). A pattern of endemism is expected to be repeated by several taxa (Morrone 2001), such that the prioritization of areas of endemism would allow the conservation of evolutionary processes (e. g., speciation and adaptation). However, areas of endemism are not commonly used in prioritization strategies (v. gr. Méndez-Larios et al. 2005).

The Mexican Mountain Component (MMC; Morrone and Márquez 2003) is inhabited by several endemic species. The MMC encompasses the main mountainous systems in Mexico, and has high geological and environmental complexity, including six biogeographical provinces (Morrone and Márquez 2003; Escalante et al. 2005): 1) the Sierra Madre Occidental in the west, 2) the Sierra Madre Oriental in the east, 3) the Transmexican Volcanic Belt of central Mexico, 4) the Balsas basin south of the Transmexican Volcanic Belt, 5) the Sierra Madre del Sur in south-central Mexico, and 6) Chiapas in the south of the country. The MMC is also known as the Mexican Transition Zone (MTZ; Halffter 1962, 1964; Escalante et al. 2005), and for some authors, it is controversial the inclusion of the Balsas basin and Chiapas provinces within it (see Morrone 2005).

Recent studies of Mexican mammals indicate that the distribution patterns of 24 endemic mammals match the pattern of MMC provinces (Aguado-Bautista and Escalante 2015; Escalante et al. 2005, 2007, 2009; Morrone 2005). Insects (Halffter 1987), plants (Andrés et al. 2006), and birds (Navarro-Sigüenza et al. 2007) exhibit similar patterns of endemism and rarity in Mexican mountains. As such, endemic species of mammals may represent adequate biodiversity surrogates for the conservation of the MMC. Mammals have been used as model taxa in several studies focusing on biogeography and conservation (Morrison et al. 2007; Eklund et al. 2011; Redford et al. 2011), and have been utilized specifically as biodiversity surrogates (see Lewandowski et al. 2010; Cantú-Ayala et al. 2013).

The mountain ecosystems of the MMC have been previously shown to be highly relevant for conservation (Cantú-Ayala et al. 2013; Suárez-Mota and Téllez-Valdés 2014). In addition, recent cartography of land use and vegetation (INEGI 2013a; http://www.inegi.org.mx/geo/contenidos/ 
recnat/usosuelo/, consulted 01/12/2014) suggests that the MMC is an area with a high coverage change in the last years. Some endemic mammals of the MMC tend to be micro-areal (with ranges, as small as a few square kilometers) and rare (with low frequency of occurrence), and are consequently often catalogued under risk categories (Table 1; SEMARNAT 2010; IUCN 2014). In addition, climate change could result in extinction of mammalian endemic species in the mountainous areas of Mexico (Ponce-Reyes et al. 2012; Aguado-Bautista and Escalante 2015).

One of the main instruments of the environmental politics in Mexico is the system of protected natural areas (PNA), which includes 176 federally protected areas (SEMARNAT 2014; http://www. conanp.gob.mx/que hacemos/, consulted 29/01/2014). In general, it has been demonstrated that PNA tends to be effective to prevent land use/land cover change (LUCC; Sánchez-Cordero and Figueroa 2007; Figueroa et al. 2011), making them an important consideration in prioritization exercises.

Here, our aims were twofold. We use patterns of endemism in mammals to: 1) prioritize conservation sites in the MMC, and 2) evaluate the current system of natural protected areas in Mexico, under the assumption that areas of endemism reflect sites whose protection conserves evolutionary processes.

\section{Materials and methods}

Mexico has a high richness of mammal species (496 species, Ramírez-Pulido et al. 2014), 38 of which are restricted to the MCC (Escalante et al. 2005). We based our analysis on small bodysized mammals endemic of the MMC (Escalante et al. 2005, 2007, 2009; Morrone 2005; Ceballos, 2014; Aguado-Bautista and Escalante 2015), whose taxonomy and distribution is considered well understood (e. g., Halffter 2004). As such, analyses were based on 24 species and subspecies (Table 1). The taxonomic nomenclature was based on the Mammals of Mexico List by Ramírez-Pulido et al. (2014) and the proposal of Fernández et al. (2014) for the families Geomyidae and Heteromyidae. The analyzed species include two rabbits, three bats, three shrews, four pocket gophers, four squirrels, and eight rats and mice. Five of these species are listed as critically endangered and one as endangered by the IUCN Red List of Threatened Species (IUCN 2014; Table 1).

We obtained 2,961 occurrence records for the 24 mammals (Table 1) from the "Biogeographic atlas of the terrestrial mammals of North America" (Escalante and Rodríguez-Tapia 2011; Escalante 2013; http://atlasbiogeografico.com/, consulted 25/06/2013). This database is available directly from the authors. The map of the MMC was obtained from Arriaga et al. (1997) and modified based on the provinces outlined by Morrone and Márquez (2003) and Escalante et al. (2005).

We modeled the distribution of the 24 species and subspecies using Maxent 3.3 (Phillips et al. 2006; Phillips and Dudík 2008). Two topographic attributes of the region (altitude and slope) and 19 environmental variables (http://edc.usgs.gov/products/elevation/gtopo30/hydro/namerica. html; http://www.worldclim.org, consulted 25/06/2013; Hijmans et al. 2005) were used as potential predictors of species distribution at a $1 \mathrm{~km}^{2}$ spatial resolution. Distribution model extent included all of Mexico. For species with $\geq 10$ records, $75 \%$ of the records were used to construct the model and $25 \%$ to validate it; for species with less than 10 records, the entire set of records was used for both model training and testing (Hernandez et al. 2006; Pearson et al. 2007). For all species, MaxEnt was executed using the following settings: 20 replicates, replicate bootstrap type, 1000 maximum iterations and convergence threshold of $1.0 \mathrm{E}-5$. The distributional model of each species was derived from the average model. All the distributional models were evaluated using the area under the receiver operating characteristic curve (AUC), considering scores greater than 0.9 as adequate (Table 1 ). 
Table 1. Endemic mammal taxa of the Mexican Mountain Component, including number of data points used in models and their conservation status. References: ${ }^{1}$ Escalante et al. (2005); ${ }^{2}$ Morrone (2005), ${ }^{3}$ Escalante et al. (2007); ${ }^{4}$ Escalante et al. (2009); ${ }^{5}$ Ceballos (2014; not registered as endemic, but with distribution restricted to the MMC); ${ }^{6}$ Aguado-Bautista and Escalante (2015). Number of datapoints (NDP). ; Conservation status* (Conservation); AUC value training (AUC); Omission rate training (OR)*NOM059-SEMARNAT-2010 (Semarnat, 2010) and Red List de la International Union for Conservation of Nature (IUCN, 2013) (http://www.iucnredlist.org; consulted 12/12/2013).

\begin{tabular}{|c|c|c|c|c|c|c|}
\hline & Taxa & Family & NDP & Conservation & AUC & OR \\
\hline 1 & Corynorhinus mexicanus ${ }^{1,6} \mathrm{G}$. M. Allen, 1916 & Vespertilionidae & 96 & Near threatened & 0.992 & 0.090 \\
\hline 2 & Cratogeomys fumosus neglectus ${ }^{1,3}$ (Merriam, 1902) & Geomyidae & 4 & & 1.000 & 0.000 \\
\hline 3 & Cryptotis goldmani' (Merriam, 1895) & Soricidae & 64 & Least concern & 0.998 & 0.097 \\
\hline 4 & Euderma maculatum $^{3}$ (J. A. Allen, 1891) & Vespertilionidae & 9 & Least concern & 0.989 & 0.097 \\
\hline 5 & Glaucomys volans ${ }^{2}$ (Linnaeus, 1758) & Sciuridae & 75 & Least concern & 0.974 & 0.098 \\
\hline 6 & Heteromys salvini ${ }^{4,6}$ Thomas, 1893 & Heteromyidae & 26 & Least concern & 0.999 & 0.096 \\
\hline 7 & Ictidomys mexicanus ${ }^{3,2}$ (Erxleben, 1777) & Sciuridae & 206 & Least concern & 0.992 & 0.098 \\
\hline 8 & Microtus mexicanus ${ }^{2,3}$ (de Saussure, 1861) & Cricetidae & 515 & Least concern & 0.999 & 0.000 \\
\hline 9 & Myotis melanorhinus ${ }^{5}$ (Merriam, 1890) & Vespertilionidae & 26 & Least concern & 0.980 & 0.098 \\
\hline 10 & Nelsonia goldmani',3 Merriam, 1903 & Cricetidae & 4 & Endangered & 1.000 & 0.000 \\
\hline 11 & Neotoma nelsoni1,3 Goldman, 1905 & Cricetidae & 4 & Critically endangered & 1.000 & 0.000 \\
\hline 12 & Neotoma palatina' Goldman, 1905 & Cricetidae & 25 & Vulnerable & 1.000 & 0.056 \\
\hline 13 & Neotomodon alstoni $i^{1,2,6}$ Merriam, 1898 & Cricetidae & 149 & Least concern & 0.999 & 0.097 \\
\hline 14 & Orthogeomys grandis $2,3,6$ (Thomas, 1893) & Geomyidae & 66 & Least concern & 0.998 & 0.095 \\
\hline 15 & Pappogeomys bulleri alcorni $i^{1,3,4}$ Russell, 1957 & Geomyidae & 3 & Critically endangered & 1.000 & 0.000 \\
\hline 16 & Peromyscus leucopus ${ }^{2,3}$ (Rafinesque, 1818) & Cricetidae & 836 & & 0.964 & 0.100 \\
\hline 17 & Reithrodontomys chrysopsis ${ }^{1,2,3,6}$ Merriam, 1900 & Cricetidae & 84 & Least concern & 0.999 & 0.093 \\
\hline 18 & Romerolagus diazi ${ }^{1,6}$ (Ferrari-Pérez, 1893) & Leporidae & 46 & Critically endangered & 0.999 & 0.077 \\
\hline 19 & Sciurus aberti durangis Thomas, 1893 & Sciuridae & 145 & Least concern & 0.996 & 0.097 \\
\hline 20 & Sciurus nayaritensis ${ }^{2,3}$ J. A. Allen, 1890 & Sciuridae & 241 & Least concern & 0.997 & 0.092 \\
\hline 21 & Sorex emarginatus 5 Jackson, 1925 & Soricidae & 16 & Least concern & 0.989 & 0.077 \\
\hline 23 & Sorex monticola monticola Merriam, 1890 & Soricidae & 5 & Least concern & 0.970 & 0.100 \\
\hline 23 & Sylvilagus insonus $s^{1,3}$ (Nelson, 1904) & Leporidae & 21 & Critically endangered & 0.999 & 0.000 \\
\hline 24 & Zygogeomys trichopus ${ }^{1,3}$ Merriam, 1895 & Geomyidae & 25 & Critically endangered & 1.000 & 0.083 \\
\hline
\end{tabular}

In order to define the threshold of environmental suitability for species, we employed the 10 percentile value of training sample points (see Escalante et al. 2013) in R-Studio ver. 3.0.1 ( Development Core Team 2013; http://www.r-project.org, consulted 05/08/2013). This value assumes that $10 \%$ of the records used for model generation are susceptible to error. In order to incorporate the historical dimension of geographical space available for species (Soberón 2010), the distributional model of each species was cropped using the MMC polygon.

To prioritize the areas, we used Maxent2ConsNet (Ciarleglio 2008) and ConsNet v. 2.0 (Ciarleglio et al. 2009; http://uts.cc.utexas.edu/ consbio/Cons/consnet home.html, consulted 13/09/2013). There are two algorithms for area selection: area minimization problem and representation maximization problem. Area minimization problem selects a set of cells with the minimum total area required for all surrogates to meets its assigned target; representation maximization maximizes the expected number of surrogates that meet their targets within a maximum total area (Margules and Sarkar 2007).

We performed several prioritization exercises using different algorithms, targets of representation for surrogates, and layers of information about PNA and land use change (LUCC). Each different exercise is called a "problem" in ConsNet. After many trials, we decided to perform 
Table 2. Prioritization problems performed in ConsNet 2.0. PNA = protected natural areas; LUCC = land use/ land cover change; $C R=$ cities and roads. Target of representation, $\%$ of the each surrogate to be protected (Target); Permanently included cells (Permanently IN); Permanently excluded cells (Permanently Ex).

\begin{tabular}{lcccl}
\hline \multicolumn{1}{c}{ Problem } & Target & Permanently IN & Permanently EX & \multicolumn{1}{c}{ Algorithm } \\
\hline Max10PNA & 10 & PNA & LUCC - CR & Maximum representation problem \\
Min10 & 10 & - & LUCC - CR & Minimum area problem \\
Min10PNA & 10 & PNA & LUCC - CR & Minimum area problem \\
Min25 & 25 & - & LUCC - CR & Minimum area problem \\
Min25PNA & 25 & PNA & LUCC - CR & Minimum area problem \\
ControlMin10 & 10 & - & - & Minimum area problem \\
ControlMin25 & 25 & - & - & Minimum area problem \\
\hline
\end{tabular}

only one exercise for the representation maximization problem algorithm and several for the area minimization problem algorithm. The advantages of the minimum area problem include its wide use, ease of understanding and implementation, excellent ability to drive search results, and lack of potential for failure (Ciarleglio et al. 2009; Hamel and Andréfouët 2012). Performed prioritization problems are shown in Table 2. All vectorial maps (shapefiles) were obtained from INEGI at a scale of 1:1,000,000 and in Lambert Conformal Conic projection: PNA ("Área Natural Protegida"; INEGI 2013b; http://www.inegi.org.mx/geo/contenidos/recnat/geologia/infoescala.aspx), roads ("Carretera"; INEGI 2013c; http://www.inegi.org.mx/geo/contenidos/topografia/ topografia 1m.aspx), cities ("Localidad Urbana"; INEGI 2013d; http://www.inegi.org.

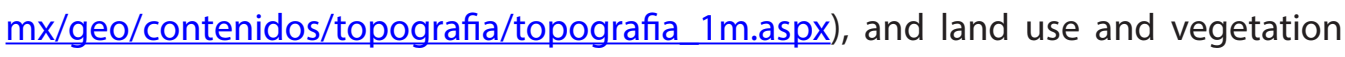
("Serie V"; INEGI 2013a; http://www.inegi.org.mx/geo/contenidos/recnat/usosuelo/). Maps were re-projected and rasterized to $1 \mathrm{~km}$ pixels, to coincide with the extent and the 24 species distribution models of surrogates.

The 42 MMC PNA were used in some problems as permanently included cells, in order to evaluate the representation of surrogates within them. LUCC was incorporated by specifying agricultural areas (including crops and pastureland), cities, and roads (considering all roads of two or more lanes and a buffer of $5 \mathrm{~km}$ along them; Cuervo-Robayo and Monroy-Vilchis 2012). Because our aim relates to conservation, for all problems, cells representing LUCC were permanently excluded, except for two problems used as controls, assuming a situation with no land modifications (Table 2). Additionally, we used two different conservation targets for surrogates: $10 \%$ and $25 \%$ of their distributional area. These targets were chosen following international goals for protected areas, as we have not analyses of population viability to calculate area sizes ensuring species persistence. However, some studies of mammals in Mexico predict a linear relationship between targets and prioritized area (Justus et al. 2008). The initial solutions were constructed through Rarity First, applying the RF4 adjacency algorithm (Ciarleglio et al. 2009, 2010; Nori et al. 2013). All problems were run with 1,000,000 iterations and standard neighborhood selection.

We used the following nomenclature to specify problems: Max: representation maximization problem; Min: area minimization problem; Control: solutions with no cells excluded or included; 10: target of $10 \%$ of representation of surrogates; 25: target of $25 \%$ of representation of surrogates; PNA: problem including the existent PNA. For example, Min10PNA refers to a solution using the area minimization problem algorithm, at $10 \%$ of target of representation of surrogates, using PNA as permanently included cells, and excluding areas with LUCC (Table 2). 
Because the best solutions will have more area with low fragmentation and high connectivity, the best solutions will be those that minimize the border effect (Fahrig 2003; Kurosawa and Askins 2003, Fletcher et al. 2007). We therefore evaluated all solutions based on their total area, perimeter, shape, number of pixels and clusters, proportion of coincidence with PNA, and they were compared between them.

\section{Results}

The best solutions for each problem are shown in Table 3 and Figures 1a-f. Comparisons of prioritized areas for each problem and PNA are shown in Table 4 and Figures $1 \mathrm{~h}-\mathrm{m}$. The best solution for Max10ANP did not reach the conservation target for any surrogate, despite having the best relation for shape. For this reason, we decided not to use this algorithm to continue the prioritization (Table 3). For shape evaluation, the Control's result problems were the best solutions (shape values closer to 0 represent less fragmentation. The representation of $25 \%$ of each surrogate requires almost three times more area than the $10 \%$ goal and leads to less fragmentation (Table 3).

Comparing among the best solutions of the Min problems with PNA, we observed that only around $15 \%$ of PNA area coincides with Min10 and Control10 (Table 4). This means that the existing PNA are not sufficient to maintain at least $10 \%$ of the distributional area of endemic mammals. It would be necessary to include more than $35,000 \mathrm{~km}^{2}$ to reach this conservation target. For Min25 and Control 25 the projection is similar; they include only $30 \%$ of the areas currently designated as PNA (adding almost 100,000 $\mathrm{km}^{2}$ ). For Min10ANP and Min25ANP the percentage of coincidence with PNA is more than $70 \%$; they do not reach a higher percentage because there are excluded cells of altered vegetation, even within the PNA (Table 4).

The total MMC area occupied by our solutions is shown in Figure 2. For Min10 and Min10PNA, almost $7 \%$ of the area of MMC is prioritized for conservation, while for Min25 and Min25ANP it is above $18 \%$. The respective control solutions are similar. The Max10PNA and only PNA have the lowest percentage of area.

\section{Discussion}

Choosing the best solution to prioritize MMC areas for endemic mammals is no an easy task. In a world without LUCC, the best solutions would clearly be those that minimize perimeter-area ratios (see ControlMin10 and ControlMin25), but LUCC-free areas no longer exist. On one hand, because larger perimeter-area ratios generate high edge effect, we prefer to use the problems considering current PNA, even though those solutions imply larger surface (for example, the difference between Min10 and Min10PNA is around 2,000 kilometers). On the other hand, Max10PNA problem was the worst solution because it does not reach the conservation targets of endemic mammals, even though it had the lowest ratio. Additionally, the proposal of a target of $25 \%$ would be probably not be economically, politically and socially viable, since this target may imply high cost and is likely to affect productive activities like forestry. Therefore, we suggest that the best scenario to prioritize areas of conservation for endemic mammals in the MMC is the Min10PNA.

The solution for the Min10PNA allows the conservation of more than 18,000 $\mathrm{km}^{2}$ of mountain areas above $2,400 \mathrm{~m}$ of elevation (corresponding to nearly $50 \%$ of the prioritized area). The majority of the Min10PNA prioritized area is located in 
Table 3. Results of prioritization problems for mammals of the MMC (Problem); Area in $\mathrm{km}^{2}$; Perimeter in $\mathrm{km}^{2}$; Shape, perimeter-area ratio (Shape); Number of selected cells (Selected cells); Number of satisfied targets (Satisfied targets); Number of clusters (clusters).

\begin{tabular}{lrrrrrr}
\hline \multicolumn{1}{c}{ Problem } & \multicolumn{1}{c}{ Area } & Perimeter & Shape & Selected cells & Satisfied targets & clusters \\
\hline Max10PNA & 5,268 & 2,035 & 0.39 & 4,266 & 0 & 47 \\
Min10 & 37,460 & 28,950 & 0.77 & 30,338 & 24 & 1,286 \\
Min10PNA & 38,565 & 28,767 & 0.75 & 31,233 & 24 & 1,250 \\
Min25 & 102,747 & 68,106 & 0.66 & 83,212 & 24 & 2,371 \\
Min25PNA & 103,471 & 67,832 & 0.66 & 83,798 & 24 & 2,405 \\
ControlMin10 & 36,371 & 18,819 & 0.52 & 29,456 & 24 & 645 \\
ControlMin25 & 96,971 & 39,710 & 0.41 & 78,534 & 24 & 965 \\
\hline
\end{tabular}

the Sierra Madre Occidental province (35\% of prioritized total area), followed by the Transmexican Volcanic Belt (30\%), and the Sierra Madre del Sur (11\%). Using the Min 10PNA, the rarest and most distributionally restricted species (the volcano rabbit or "teporingo", Romerolagus diazi), is conserved in $62 \%$ of its distributional area, which is of interest since it is critically endangered (Table 1).

There are some exercises of prioritization of areas in Mexico, but not for the MMC. Fuller et al. (2007) warned about the cost of postponing conservation actions in Mexico. They prioritized areas using the minimization problem and a target of $10 \%$, obtaining similar areas for the MMC, although they used a different concept of endemism. For southern Mexico, Urbina-Cardona and Flores-Villela (2010) prioritized areas for the herpetofauna, many of them in mountain areas coinciding with our southern MMC; however, their concept of endemism did not consider sympatry. Illoldi-Rangel et al. (2012) performed a multi-criterion analysis in order to prioritize areas for Mexican species of Opuntia; they concluded that all plans would require around one-third of Mexican territory and high connectivity. However, we think that decisions about connectivity should be considered with caution, since each biogeographic province has its own evolutionary history and excessive connectivity may force the joining of areas and biotas with different histories which are naturally disjoint.

For the Transmexican Volcanic Belt province, some prioritization exercises have been performed (Sánchez-Cordero et al. 2005; Fuller et al. 2006; Suárez-Mota and Téllez-Valdés 2014). For example, Fuller et al. (2006) proposed a network of protected areas for 99 species of mammals, based on an algorithm of rarity, complementarity, and connectivity. These authors coincide with the fact that the current system of protected areas does not adequately represent biodiversity. Suárez-Mota and Téllez-Valdés (2014)

Table 4. Comparisons of prioritization problems for mammals of the MMC. Area $\left(\mathrm{km}^{2}\right)$ intersected (Area); \% represented of the PNA (\% PNA); Area $\left(\mathrm{km}^{2}\right)$ exclusive of each problem wit-hout PNA (Area without PNA); $\operatorname{Area}\left(\mathrm{km}^{2}\right)$ of PNA (Area PNA).

\begin{tabular}{lcrrr}
\hline \multicolumn{1}{c}{ Problem } & \multicolumn{1}{c}{ Area } & \% PNA & Area without PNA & Area PNA \\
\hline PNA $\Omega$ Min10 & 1,091 & 15.23 & 36,263 & 6,017 \\
PNA $\Omega$ Min10PNA & 5,370 & 74.98 & 33,062 & 1,738 \\
PNA $\Omega$ Min25 & 2,491 & 34.78 & 99,923 & 4,617 \\
PNA $\Omega$ Min25PNA & 5,602 & 78.22 & 97,514 & 1,506 \\
PNA $\Omega$ ControlMin10 & 1,038 & 14.49 & 35,263 & 6,070 \\
PNA $\Omega$ ControlMin25 & 2,047 & 28.58 & 94,673 & 5,062 \\
\hline
\end{tabular}



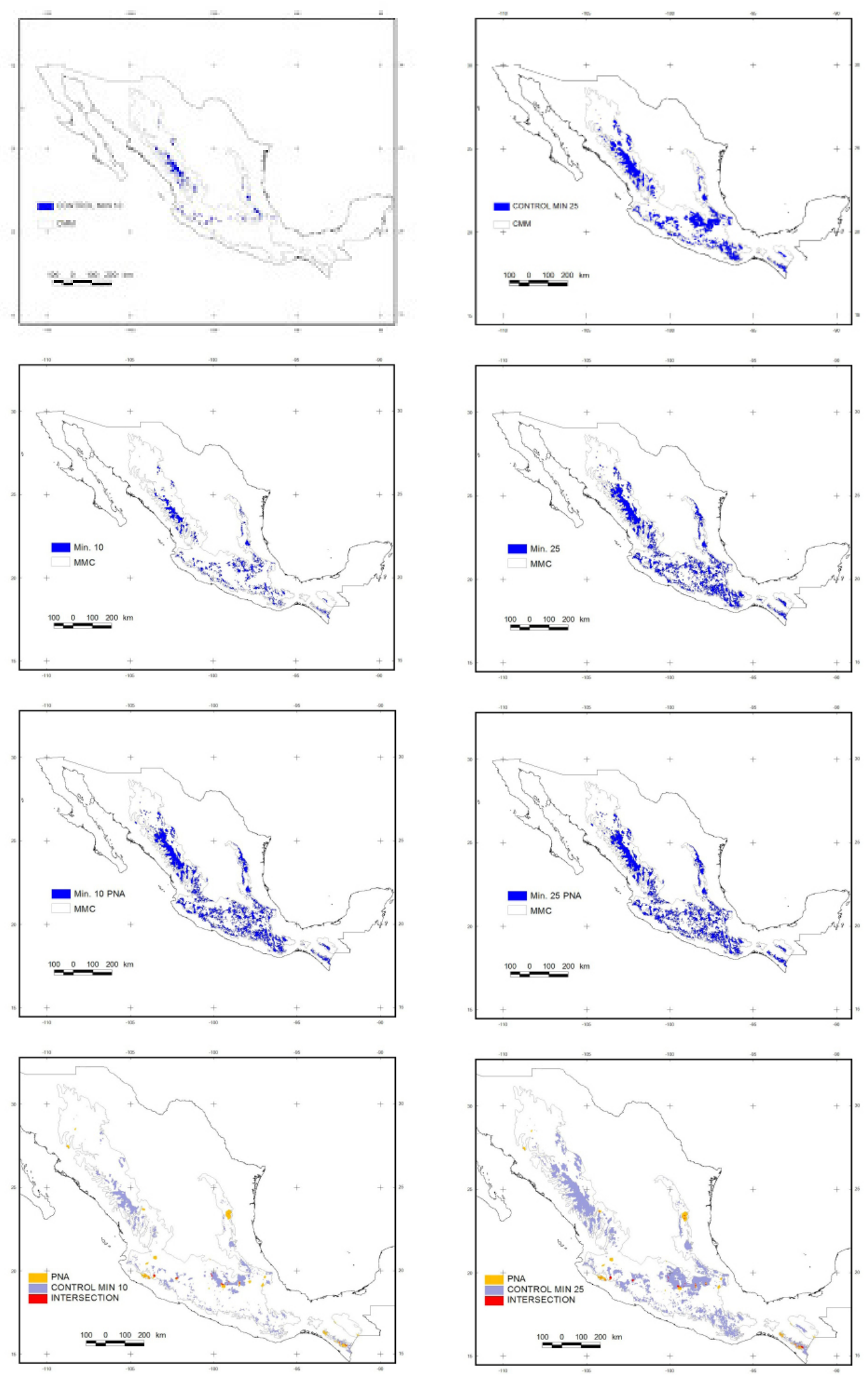

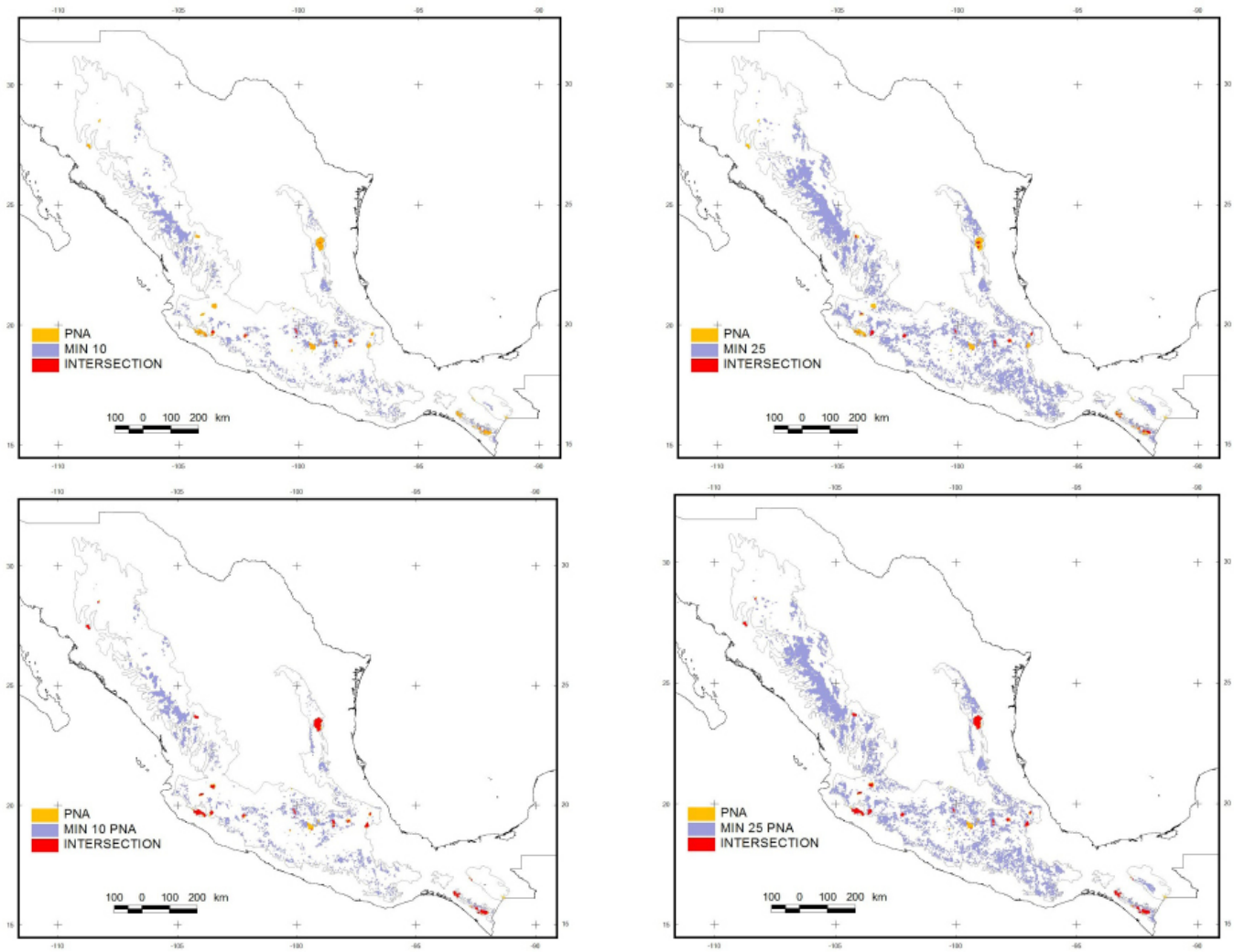

Figure 1. Maps show the pixels prioritized in the Mexican Mountain Component (MMC). A) Best solution for the ControlMin 10 problem (a problem is an exercise of prioritization under particular conditions, see Table 2). B) Best solution for the ControlMin25 problem. C) Best solution for the Min10 problem. D) Best solution for the Min25 problem. E) Best solution for the Min10PNA problem. F) Best solution for the Min25PNA problem. G) Comparison between prioritized areas for the ControlMin10 problem and the protected natural areas (PNA). H) Comparison between prioritized areas for the ControlMin 25 problem and the protected natural areas (PNA). I) Comparison between prioritized areas for the Min 10 problem and the protected natural areas (PNA). J) Comparison between prioritized areas for the Min25 problem and the protected natural areas (PNA). K) Comparison between prioritized areas for the Min10PNA problem and the protected natural areas (PNA). L) Comparison between prioritized areas for the Min25PNA problem and the protected natural areas (PNA). M) Percentage of MMC area occupied by the best solutions of all the minimum area problems, including the PNA and Max10PNA.

agree that it is necessary to include areas in conservation priorities not considered in the current PNA. Also, there are other prioritization exercises for particular areas in Mexico, which partially covered the MMC (v. gr. Illoldi-Rangel et al. 2008).

Mountainous areas for conservation that has been prioritized based on other criteria coincide with our findings. For example, an area with high phylogenetic endemism for mammals was identified in Central Mexico, possibly associated with high elevation and topographic complexity (Rosauer and Jetz 2014). The cloud forest of Chiapas should be protected because it could decline dramatically by 2080 (Ponce-Reyes et al. 2012), although, in fact, all of southeastern Mexico requires special attention (Cantú-Ayala et al. 2013). In addition, the vulnerability of endemic species of mountainous areas could be high for some areas of endemism, such as the Transmexican Volcanic Belt, the East District, Soconusco and the MTZ (Aguado-Bautista and Escalante 2015).

It would be necessary to quantify in detail the congruence among our proposal and all other approaches in order to obtain a more robust proposal to present to stakeholders. In addition, the incorporation of land costs will be a strong determinant to implementing any conservation plan for the MMC (v. gr. Fletcher et al. 2013); similarly, vulnerability studies should be incorporated. Moreover, it is necessary to evaluate the current system of protected areas, in particular with respect to their effectiveness for maintaining ecosystems facing the effects of climate change 


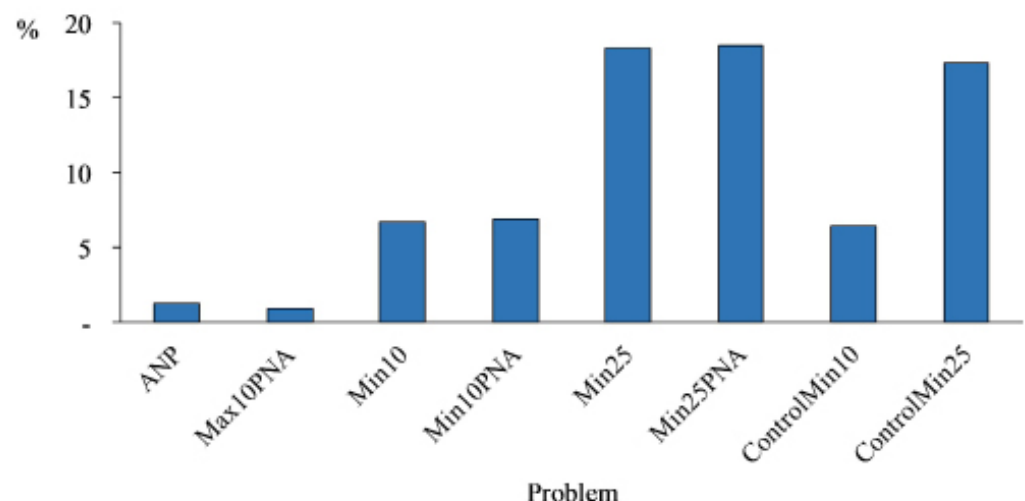

Figure 2. Percentage of MMC area occupied by the best solutions of all the minimum area problems, including the PNA and Max10PNA.

and LUCC (v. gr. Figueroa et al. 2011; Ponce-Reyes et al. 2012). Finally, concepts of endemism as a biogeographic pattern should be standarized to generate a more integrated general approach (see Noguera-Urbano 2016).

Patterns of endemism can provide adequate surrogates for SCP. The current system of PNA is shown to be insufficient to conserve the distributional areas of 24 endemic mammals of the MMC. A strategy based on prioritizing areas using the solution that considers the area minimization problem with a target of $10 \%$ of distribution of the endemic mammals as surrogates, including PNA and other areas, and excluding altered vegetation, can help to maintain the distributional patterns of endemism of the Mexican biota. However, comparisons with other prioritization exercises are necessary in order to propose an efficient and effective system of protected areas in Mexico.

\section{Acknowledgements}

The CONACyT project 80370 partially supports this research. We are thankful for the discussions at the XI Reunión Argentina de Cladística y Biogeografía at Santa Fé (2014). J. J. Morrone, K. Mainali, C. Szumik and one anonymous reviewer made useful comments that helped to improve the manuscript.

\section{Literature cited}

Aguado-Bautista, O., and T. Escalante. 2015. Cambios en los patrones de endemismo de los mamíferos terrestres de México por el calentamiento global. Revista Mexicana de Biodiversidad 86:99-110.

Andrés, A. R., J. J. Morrone, T. Terrazas, and L. López Mata. 2006. Análisis de trazos de las especies mexicanas de Rhus subgénero Lobadium (Angiospermae: Anacardiaceae). Interciencia 31:900-904.

Arriaga, L., C. Aguilar, D. Espinosa-Organista, and R. Jiménez. 1997. Regionalización ecológica y biogeográfica de México. Comisión Nacional para el Conocimiento y Uso de la Biodiversidad (Conabio). Ciudad de México, México.

Bonn, A., A. S. Rodrigues, AND K. J. Gaston. 2002. Threatened and endemic species: are they good indicators of patterns of biodiversity on a national scale? Ecology Letters 5:733-741.

Cantú-Ayala, C. M., J. R. Estrada-Arellano, M. M. Salinas Rodríguez, J. G. Marmolejo-Moncivais, and E. A. Estrada Castillón. 2013. Vacíos y omisiones en conservación de las ecorregiones de montaña en México. Revista Mexicana de Ciencias Forestales 4:10-27. 
Ceballos, G. (ed.) 2014. Mammals of Mexico. Johns Hopkins University Press. Baltimore, EE. UU. CiARLeGlio, M. 2008. Maxent2ConsNet manual ver 1.00. University of Texas-Austin. Austin, EE. UU. Ciarleglio, M., J. W. Barnes, and S. Sarkar. 2009. ConsNet: new software for the selection of conservation area networks with spatial and multi-criteria analyses. Ecography 32:205-209.

Ciarleglio, M., J. W. Barnes, and S. Sarkar. 2010. ConsNet-A tabu search approach to the spatially coherent conservation area network design problem. Journal of Heuristics 16:537-557.

Cuervo-Robayo, A. P., And O. Monroy-Vilchis. 2012. Distribución potencial del jaguar Panthera onca (Carnivora: Felidae) en Guerrero, México: persistencia de zonas para su conservación. Revista de Biología Tropical 60:1357-1367.

Di Minin E., And A. Moilanen. 2014. Improving the surrogacy effectiveness of charismatic megafauna with well-surveyed taxonomic groups and habitat types. Journal of Applied Ecology 51:281-288.

Eklund, J., A. Arponen, P.Visconti, and M. Cabeza. 2011. Governance factors in the identification of global conservation priorities for mammals. Philosophical Transactions of the Royal Society B 366:2661-2669.

Escalante, T. 2013. Atlas biogeográfico de los mamíferos terrestres de América del Norte: una nueva opción en internet. Therya 4:5-8.

Escalante, T., and G. Rodríguez-Tapia. 2011. Base de datos geoespacial de mamíferos terrestres de América del Norte: una aproximación a sus patrones biogeográficos y conservación. Pp. 110-113. in Memorias de la XIX Reunión Nacional SELPER-México (Mas, J. F., G. Cuevas, and R. González, comps.). Centro de Investigaciones en Geografía Ambiental, UNAM. Morelia, México.

Escalante, T., G. Rodríguez-Tapia, M. Linaje, P. Illoldi-Rangel, and R. González-López. 2013. Identification of areas of endemism from species distribution models: threshold selection and Nearctic mammals. TIP Revista Especializada en Ciencias QuímicoBiológicas 16:5-17.

Escalante, T., G. Rodríguez, and J. J. Morrone. 2005. Las provincias biogeográficas del componente Mexicano de Montaña desde la perspectiva de los mamíferos continentales. Revista Mexicana de Biodiversidad 76:199-205.

Escalante, T., V. Sánchez-Cordero, J. J. Morrone, and M. Linaje. 2007. Areas of endemism of Mexican terrestrial mammals: A case study using species' ecological niche modeling, Parsimony Analysis of Endemicity and Goloboff fit. Interciencia 32:151-159.

Escalante, T., C. Szumik, and J. J. Morrone. 2009. Areas of endemism of Mexican mammals: Re-analysis applying the optimality criterion. Biological Journal of the Linnean Society 98:468-478.

FAHRIG, L. 2003. Effects of habitat fragmentation on biodiversity. Annual Review of Ecology, Evolution, and Systematics 34:487-515.

FAITH,D.P., C.A.M.Reid, AND J.Hunter. 2004. Integrating phylogenetic diversity, complementarity, and endemism for conservation assessment. Conservation Biology 18:255-261.

Fernández, J. A., M. S. Hafner, D. J. Hafner, and F. A. Cervantes. 2014. Conservation status of rodents of the families Geomyidae and Heteromyidae of Mexico. Revista Mexicana de Biodiversidad 85:576-588.

Figueroa, F., V. Sánchez-Cordero, P. Illoldi-Rangel, and M. Linaje. 2011. Evaluación de la efectividad de las áreas protegidas para contener procesos de cambio en el uso del suelo y la vegetación. ¿Un índice es suficiente? Revista Mexicana de Biodiversidad 82:951-963. 
Fletcher, Jr. R. J., L. Ries, J. Battin, and A. D. Chalfoun. 2007. The role of habitat area and edge in fragmented landscapes: definitively distinct or inevitably intertwined? Canadian Journal of Zoology 85:1017-1030.

Fuller, T. M., M. Munguía, M. Mayfield, V. Sánchez-Cordero, and S. Sarkar. 2006. Incorporating Connectivity into Conservation Planning: A Multi-Criteria Case Study from Central Mexico. Biological Conservation 133:131-142

Fuller, T. M., V. Sánchez-Cordero, P. Illoldi-Rangel, M. Linaje, and S. Sarkar. 2007. The cost of postponing biodiversity conservation. Biological Conservation 134:593-600.

Fuller, T. L., H. A. Thomassen, M. Peralvo, W. Buermann, B. Milá, C. M. Kieswetter, P. Jarrín-V., S. E. C. Devitt, E. Mason, R. M. Schweizer, J. Schlunegger, J. Chan, O. Wang, C. J. Schneider, J. P. Pollinger, S. Saatchi, C. H. Graham, R. K. Wayne, and T. B. Smith. 2013. Intraspecific morphological and genetic variation of common species predicts ranges of threatened ones. Proceedings of the Royal Society of London B 280:20130423.

Hafner, M. S., T. A. Spradling, J. E. Light, D. J. Hafner, and J. R. Demboski. 2004. Systematic revision of pocket gophers of the Cratogeomys gymnurus species group. Journal of Mammalogy 85:1170-1183.

Halffter, G. 1962. Explicación preliminar de la distribución geográfica de los Scarabaeidae mexicanos. Acta Zoológica Mexicana 5:1-17.

Halffter, G. 1964. La entomofauna americana, ideas acerca de su origen y distribución. Folia Entomologica Mexicana 6:1-108.

Halffter, G. 1987. Biogeography of the montane entomofauna of Mexico and Central America. Annual Review of Entomology 32:95-114.

Hamel, M.A., And S. Andréfouët. 2012. Biodiversity-based propositions of conservation areas in Baa Atoll, Republic of Maldives. Atoll Research Bulletin 590:223-235.

Hernandez, P. A., C. H. Graham, L. L. Master, and D. L. Albert. 2006. The effect of sample size and species characteristics on performance of different species distribution modeling methods. Ecography 29:773-785.

Hijmans, R. J., S. E. Cameron, J. L. Parra, P. G. Jones, and A. Jarvis. 2005. Very high resolution interpolated climate surfaces for global land areas. International Journal of Climatology 25:1965-1978.

Illoldi-Rangel, P., M. Ciarleglio, L. Sheinvar, M. Linaje, V. Sánchez-Cordero and S. Sarkar. 2012. Opuntia in Mexico: Identifying Priority Areas for Conserving Biodiversity in a MultiUse Landscape. PLoS ONE 7: e36650.

Illoldi-Rangel, P., T. Fuller, M. Linaje, C. Pappas, V. Sánchez-Cordero, and S. Sarkar. 2008. Solving the Maximum Representation Problem to Prioritize Areas for the Conservation of Terrestrial Mammals at Risk in Oaxaca. Diversity and Distributions 14:493-508.

INEGI. 2013a. Uso de suelo y vegetación. Datos vectoriales escala 1:250 000 Serie V (Capa Unión). Instituto Nacional de Estadística y Geografía. Available at http://www.inegi. org.mx/geo/contenidos/recnat/usosuelo/. (accessed December 2013).

INEGI. 2013b. Área Natural Protegida. Recursos Naturales. Datos vectoriales escala 1: 1 000 000. Available at http://www.inegi.org.mx/geo/contenidos/recnat/ (accessed October 2013).

INEGI. 2013c. Topografía. Datos vectoriales 1:1,000,000. Available at http://www.inegi.org. mx/geo/contenidos/topografia/topografia_1m.aspx (accessed October 2013).

INEGI. 2013d. Localidad Urbana. Topografía. Datos vectoriales 1:1 000 000. Available at http://www.inegi.org.mx/geo/contenidos/topografia/topografia_1m.aspx (accessed October 2013).

IUCN. 2014. The IUCN Red List of Threatened Species. Version 2013.2. Available at http:// www.iucnredlist.org. (accessed December 2013). 
Justus, J., T. Fuller, And S. SARKar. 2008. Influence of representation targets on the total area of conservation-area networks. Conservation Biology 22:673-682.

Kurosawa, R., And R. A. Askins. 2003. Effects of habitat fragmentation on birds in deciduous forests in Japan. Conservation Biology 17:695-707.

Lewandowski, A. S., R. F. Noss, And D. R. Parsons. 2010. The effectiveness of surrogate taxa for the representation of biodiversity. Conservation Biology 24:1367-1377.

Luna-Vega, I., J. J. Morrone, and T. Escalante. 2010. Conservation biogeography: A viewpoint from evolutionary biogeography. Pp. 229-240 in Biogeography (Gailis, M., and S. Kalninjs, eds.). Nova-Science Publishers. New York, EE. UU.

Margules, C. R., and S. Sarkar. 2007. Systematic conservation planning. Cambridge University Press. Cambridge, United Kindom.

Méndez-Larios, I., J. L. Villaseñor, R. Lira, J. J. Morrone, P. Dávila, and E. Ortiz. 2005. Toward the identification of a core zone in the Tehuacán-Cuicatlán biosphere reserve, Mexico, based on parsimony analysis of endemicity of flowering plant species. Interciencia 30:264-274.

Morrison, J. C., W. Sechrest, E. Dinerstein, D. S. Wilcove, and J. F. Lamoreux. 2007. Persistence of large mammal faunas as indicators of global human impacts. Journal of Mammalogy 88:1363-1380.

Morrone, J. J. 1994. On the identification of areas of endemism. Systematic Biology 43:438-441.

Morrone, J. J. 2001. Homology, biogeography and areas of endemism. Diversity and Distributions 7:297-300.

Morrone, J. J. 2005. Hacia una síntesis biogeográfica de México. Revista Mexicana de Biodiversidad 76:207-252.

Morrone, J. J., And T. Escalante. 2009. Diccionario de biogeografía. Las prensas de Ciencias. Ciudad de México, México.

MorRone, J. J., AND J. MÁrquez. 2003. Aproximación a un atlas biogeográfico mexicano: componentes bióticos principales y provincias biogeográficas. Pp. 217-220 in Una perspectiva lationoamericana de la biogeografía (Morrone, J. J., and J. Llorente, eds.). Las Prensas de Ciencias, UNAM. Ciudad de México, México.

Navarro-Sigüenza, A. G., A. Lira-Noriega, A. T. Peterson, A. Oliveras-de Ita, and A. GordilloMartínez. 2007. Diversidad, endemismo y conservación de las aves. Pp. 461-484 in Biodiversidad de la Faja Volcánica Transmexicana (Luna, I., J. J. Morrone, and D. Espinosa, eds.). Universidad Nacional Autónoma de México. Ciudad de México, México.

Noguera-Urbano, E. A. 2016. Areas of endemism: traveling through the space and the unknown dimension. Systematics and Biodiversity 14:131-139.

Nori, J., J. N. Lescano, P. Illoldi-Rangel, N. Frutos, M. R. Cabrera, and G. C. Leynaud. 2013. The conflict between agricultural expansion and priority conservation areas: Making the right decisions before it is too late. Biological Conservation 159:507-513.

Pearson, R. G., C. J. Raxworthy, M. Nakamura, and T. A. Peterson. 2007. Predicting species distributions from small numbers of occurrence records: a test case using cryptic geckos in Madagascar. Journal of Biogeography 34:102-117.

Phillips, S. J., ANd M. Dudík. 2008. Modelling of species distributions with Maxent: new extensions and a comprehensive evaluation. Ecography 31:161-175.

Phillips, S. J., R. P. Anderson, And R. E. Schapire. 2006. A maximum entropy modelling of species geographic distributions. Ecological Modelling 190:231-259.

Ponce-Reyes, R., V. H. Reynoso-Rosales, J. E. Watson, J. Vanderwal, R. A. Fuller, R. L. Pressey, and H. P. Possingham. 2012. Vulnerability of cloud forest reserves in Mexico to climate change. Nature Climate Change 2: 448-452. 
Reynoso-Rosales, J. E. Watson, J. Vanderwal, R. A. Fuller, R. L. Pressey, and H. P. Possingham. 2012. Vulnerability of cloud forest reserves in Mexico to climate change. Nature Climate Change 2:448-452.

Posadas, P., D. R. Miranda-Esquivel, And J. V. CRisci. 2001. Using phylogenetic diversity measures to set priorities in conservation: an example from Southern South America. Conservation Biology 15:1325-1334.

R Development Core Team. 2013. R: A language and environment for statistical computing. ver. 3.0.1. R Foundation for Statistical Computing,Vienna, Austria. Available at http:// www.R-project.org.

Ramirez-Pulido, J., N. Gonzalez-Ruiz, A. L. Gardner, and J. Arroyo-Cabrales. 2014. List of recent land mammals from Mexico. Special Publications Museum of Texas Tech University 63:1-69.

Redford, K. H., J. C. RaY, and L. Boitanı. 2011. Mapping and navigating mammalian conservation: from analysis to action. Philosophical Transactions of the Royal Society B 366:2712-2721.

Rosauer D. F., and W. Jetz. 2014. Phylogenetic endemism in terrestrial mammals. Global Ecology and Biogeography 24:168-179.

Sánchez-Cordero, V., V. Cirelli, M. Munguia, and S. Sarkar. 2005. Place prioritization for biodiversity representation using ecological niche modeling. Biodiversity Informatics 2:211-223.

Sánchez-Cordero, V., and F. Figueroa. 2007. La efectividad de las reservas de la biosfera en México para contener procesos de cambio en el uso de suelo y la vegetación. Pp 161-171, in Hacia una cultura de conservación de la diversidad biológica (Halffter, G., S. Guevara, and A. Melic, eds.). m3m: Monografías Tercer Milenio vol. 6, S.E.A. Zaragoza, España.

SEMARNAT. 2010. NOM059-SEMARNAT-2010. Protección ambiental-Especies nativas de México de flora y fauna silvestres-Categorías de riesgo y especificaciones para su inclusión, exclusión o cambio-Lista de especies en riesgo. Secretaría de Medio Ambiente y Recursos Naturales. Diario Oficial de la Federación, December 30, 2010.

SEMARNAT. 2014. Áreas protegidas decretadas. Secretaría de Medio Ambiente y Recursos Naturales. Available at http://www.conanp.gob.mx/que_hacemos/. Accessed 29/01/2014.

SOBERón, J. M. 2010. Niche and area of distribution modeling: a population ecology perspective. Ecography 33:159-167.

SuÁrez-Mota, M. E., AND O.Téllez-VALdÉs. 2014. Red de áreas prioritarias para la conservación de la biodiversidad del Eje Volcánico Transmexicano analizando su riqueza florística y variabilidad climática. Polibotánica 38:67-93.

Urbina-Cardona, N., and O. Flores-Villela. 2010. Ecological-niche modeling and prioritization of conservation-area networks for Mexican herpetofauna. Conservation Biology 24:1031-1041.

Vane-Wright, R. I., C. J. Humphries, And P. H. Williams. 1991. What to protect? Systematics and the agony of choice. Biological Conservation 55:235-254.

Whittaker, R. J., M. B. Araújo, P. Jepson, R. J. Ladle, J. E. M. Watson, and K. J. Willis. 2005. Conservation Biogeography: Assessment and prospect. Diversity and Distributions 11:3-23. 
Submited: August 21, 2015

Reviewed: November 24, 2015

Accepted: March 2, 2016

Associated editor: Guillermo D'Elía 
